短 報

\section{外来頸肩腕障害患者に対する考察（第1 報）}

Considerations of the Cervicobrachial Syndrome (Part 1)

近来，チェーンストアのチェッカーや，保母の頸肩腕 障害が増加し，われわれ病院におけるこれらの患者の増 加も, ここ $1 \sim 2$ 年著しいものがあるので, 1972年度ま での外来頸肩腕障害患者のまとめを行ない, 大方のご枇 判をらけたいと思う。

\section{対 象}

われわれの病院でとり扱った職業起因性と思われるス 一パー関係のチェッカー, 公私立保育所, 身障者収容施 設の保母, その他タイピスト, キーパンチャー, 電話交 換手等の頸肩腕障害と思われる外来患者のうち，1973年 3 月末までに来院した約 300 人の中から，比較的資料の 整備されている者を対象とした. これらのらち，前二者 は比較的数も多いので,一応職種別に分類し, 他は一括 して分類した。

1. 自覚症状について（図 1-a, b , c ) : 図 1 は, 産 業衛生学会のアンケートのらち, いつもあると答えた者 のみを図にしたものであるが，いずれの職種においても 右の肩こり，腕のたるさ等を共通して訴えているが，チ

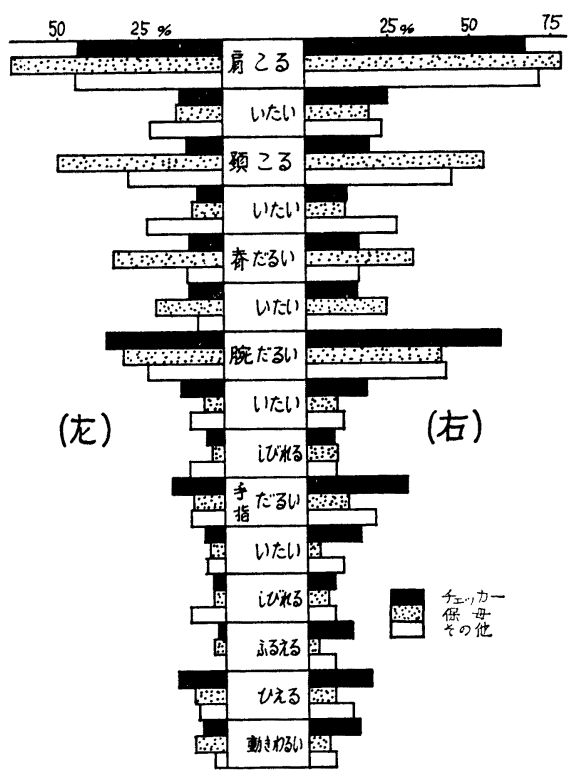

図1-a． 頸腕障害患者の自覚症調査（1973. 3， 東神戸病院）
エッカーでは, 右肩こり, 右腕のだるさ, 手指のだるさ の順に訴えが多く, 保母では肩こり, 頸のこり, 腕のだ るさの順になって，一般的に右側が強い.

下半身についてみれば，保母の場合他職種にくらべて 腰のだるさ，痛さ，下肢のだるさを日常的に訴えるもの が圧倒的に多いのが目立つ。

全身症状からみると, 目や耳等の感覚器の症状は一般 的に少ないが，体がだるいと常時訴えている者が多く， とくに保母の場合, 約73\%とはなはだしく高率である. その他，保母の場合，いらいらするとか，胃腸がわるい と答えた者が，他より多いこととあわせて職種の特徴で あるかもしれない。

2. 日常生活の不便苦痛について（図2）：図2は, いつも感じていることのみをグラフにしたものである が，第 6 項の，字を書くとつらいというのは，各職種と も半数以上が訴えている. 日常的にも手紙を書いたり, レポートを書いたりすることに，苦痛を訴える患者が多

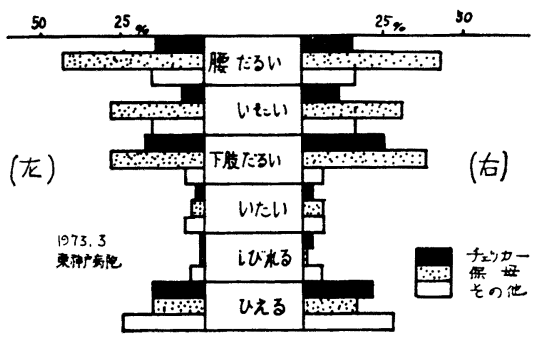

図 1-b. 頸腕障害患者の自覚症状調査 (1973. 3，東神戸病院）

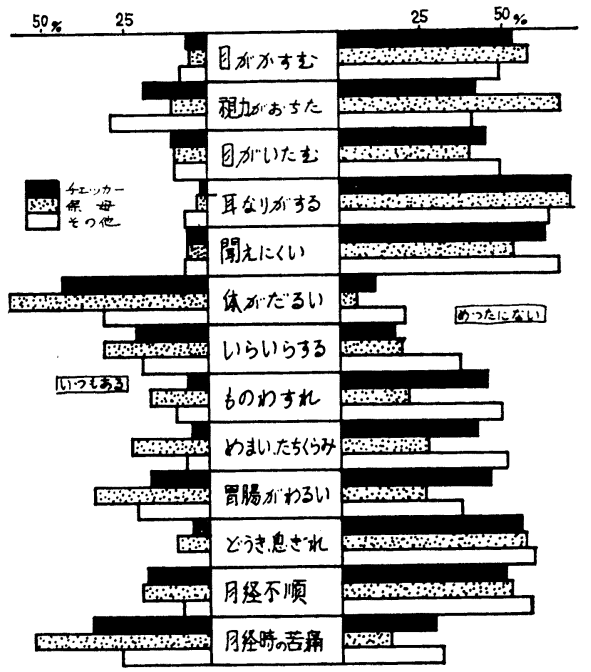

困 1-c。頸腕障害患者の自覚症状調査 （1973. 3，東神戸病院） 

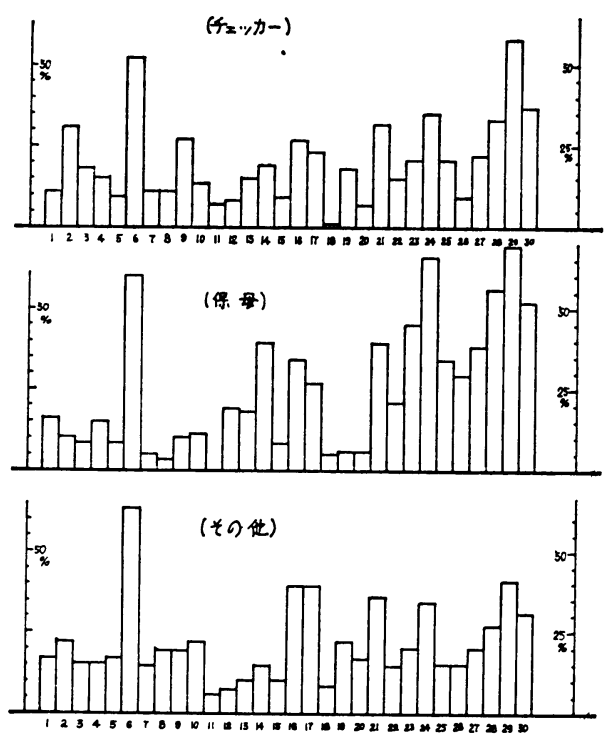

図 2. 日常生活の不便・苦痛について
いことと一致する. 16 項の, 天候の悪い時に体の調子が 悪いとか, 17項の, 冷房がつらいとか, 21項の, ねつき が覀い, 24項の, 本をつづけて読めない, 28項, じっと すわっていられない，29項，横になりたい，30項の，痛 みのためゆららつ等の項目もあんがい共通して多いよう である。

各職種別にみると，チェッカーでは 6 項と 29 項がとく に多いが，保母では21項以下の神経疲労を中心とする項 目の訴えが多いのが特徵的である.その他の職種では, 6 項をのぞいて他はだいたい平均化されているようであ る.

3. C.M.I.; 頸運動; 筋力テスト; 皮膚温；レントゲ ン所見および初診時の治療方針については, 続報にゆず りたい.

飾森 望, 岸本洋子, 石井俊三, 真鍋尊雄 東神戸病院 (院長 : 成味秀世)

Nozomu Sikimori, Yohko Kishimoto, Shunzoh IsHII and Yoshio Manabe

Higashi Kohbe Hospital (Director: H. NARUMI) 昭和48年10月17日受付 